\title{
The Wounded Heart
}

\section{Chicana Matters Series}

Deena J. González and Antonia Castañeda, editors

Chicana Matters Series focuses on one of the largest population groups in the United States today, documenting the lives, values, philosophies, and artistry of contemporary Chicanas. Books in this series may be richly diverse, reflecting the experiences of Chicanas themselves, and incorporating a broad spectrum of topics and fields of inquiry. Cumulatively, the books represent the leading knowledge and scholarship in a significant and growing field of research and, along with the literary works, art, and activism of Chicanas, underscore their significance in the history and culture of the United States. 


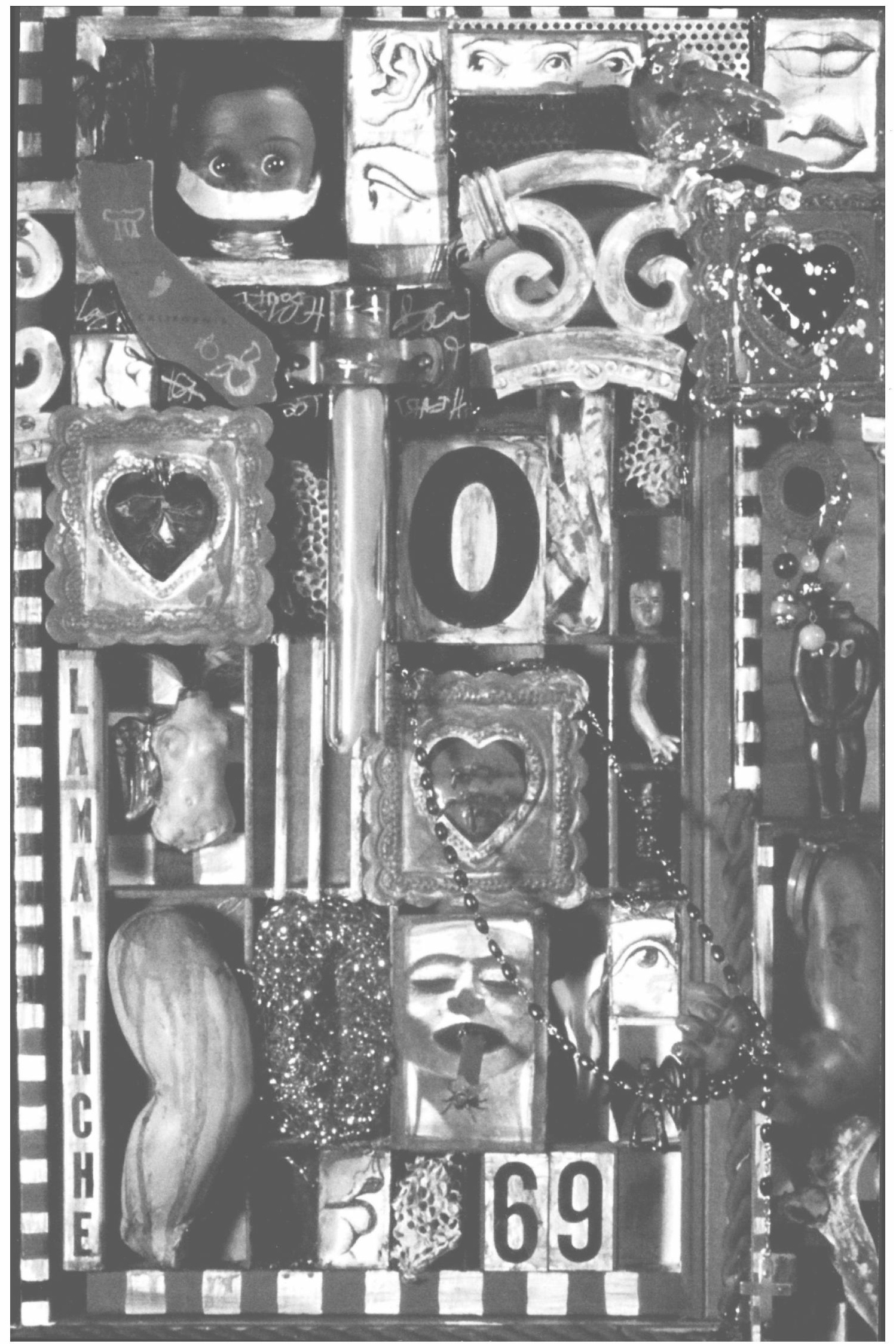




\section{The Wounded Heart Writing on Cherrie Moraga}

Yvonne Yarbro-Bejarano

University of Texas Press 
An earlier version of chapter 1 appeared as "Deconstructing the Lesbian Body: Cherríe Moraga's Loving in the War Years," in Chicana Lesbians: The Girls Our Mothers Warned Us About, ed. Carla Trujillo (Berkeley: Third Woman Press, 1991). An earlier version of chapter 2 appeared as "Cherríe Moraga's Giving Up the Ghost: The Representation of Female Desire," in Third Woman, 3: 1 and 2 (1986).

An earlier version of chapter 3 appeared as "Cherríe Moraga's 'Shadow of a Man': Touching the Wound in Order to Heal," in Acting Out: Feminist Performances, eds. Lynda Hart and Peggy Phelan (Ann Arbor: University of Michigan Press, 1993).

Illustrations in this book are details from an assemblage by Sheri Tornatore.

Copyright $(2001$ by the University of Texas Press

All rights reserved

Printed in the United States of America

First edition, 2001

Requests for permission to reproduce material from this work should be sent to Permissions, University of Texas Press, Box 7819, Austin, TX 78713-7819.

\section{Library of Congress Cataloging-in-Publication Data}

Yarbro-Bejarano, Yvonne.

The wounded heart : writing on Cherríe Moraga /

Yvonne Yarbro-Bejarano. - 1st. ed. p. $\quad \mathrm{cm} . \quad-$ (Chicana matters series)

Includes bibliographical references and index.

ISBN 0-292-79607-2 (alk. paper) ISBN 0-292-79608-o (pbk. : alk. paper)

1. Moraga, Cherríe-Criticism and interpretation.

2. Women and literature-United States-History-2oth century. 3. Mexican American women in literature. 4. Mexican Americans in literature. 5. Lesbians in literature. I. Title. II. Series.

PS3563.0753 z96 2001

$818^{\prime} .5409-$ dc21 2001017139

ISBN 978-0-292-75987-9 (library e-book)

ISBN 978-0-292-78549-6 (individual e-book) 
Dedicated to Eleanor Soto

In Memoriam

Lora Romero

(1960-1997)

Raquel Mendieta

(1951-1999) 
THIS PAGE INTENTIONALLY LEFT BLANK 